\title{
Properties and fibre characterisation of bleached hemp, birch and pine pulps: a comparison
}

\author{
Dariusz Danielewicz $\mathbb{D}$ ・ Barbara Surma-Ślusarska
}

Received: 13 March 2017/Accepted: 29 August 2017/Published online: 15 September 2017

(C) The Author(s) 2017. This article is an open access publication

\begin{abstract}
The papermaking potential of bleached kraft pulps made from hemp stalks, hemp woody-core and hemp bast fibres was studied and compared with that of bleached birch pulp and pine kraft pulp. It has been shown that among the pulps from these raw materials, hemp stalk pulp has the most useful properties for papermaking. The disadvantages of hemp woody-core pulp and hemp bast fibre pulp as papermaking intermediates proved to be low tear resistance and low tensile strength, respectively. Results indicate that the main reasons for the low tensile strength of hemp bast fibre pulp are the low susceptibility of their fibres for internal fibrillation and low hemicellulose content. The technology used in this work for the processing of hemp bast fibres into papermaking pulp made it possible to obtain pulp with high $\alpha$-cellulose content from this fibrous raw material with a high yield in a much simpler way than when such pulps are obtained from wood.
\end{abstract}

Keywords Bleached hemp pulps · ECF bleaching . Beating curve · Pulps' properties · Fibre morphology

D. Danielewicz $(\bowtie) \cdot$ B. Surma-Ślusarska

Division of Papermaking Fibrous Pulps Technology,

Institute of Papermaking and Printing, Technical

University of Lodz, Wolczanska 223 Street, 90-924 Lodz,

Poland

e-mail: darekdan@wp.pl

\section{Introduction}

The development of the world economy, the increase of demand for wood and the deterioration of forests have seriously threatened natural wood resources. Therefore, the pulp and paper industry, which produces about $40 \%$ of its products directly from wood, takes action to obtain fibres from forest plantations (Tarnawski 2006; Christersson 2010), producing papers and paperboards with a growing proportion of waste paper (Miranda et al. 2010) and mechanical pulps (Ford and Sharman 1996) and seeking possibilities to increase the yield of kraft pulps from wood (Bach and Fiehn 1972; Hart and Rudie 2014). Another possibility to reduce the dependence of the industry on wood is to use non-wood plant fibrous raw materials (NPFRMs) to produce papermaking pulps (Guadalix et al. 1996; Paavilainen 1998; Vargas et al. 2012; Danielewicz et al. 2015).

For NPFRM that can be used to make papers and boards, one can include primarily cereal straw, straw of plants grown for industrial purposes, as well as stalks of wild plants (Sadawarte 1995; Meeusen-van 1996; Potter 1996; Paavilainen 1998; Edelman 2000; Kane 2000; Schott et al. 2001; Jain et al. 2005; Xiaorong and Oinonen 2007; Zhu 2008). In 2010, virgin pulps from NPFRM accounted for $9.1 \%$ of the production worldwide of all such pulps (Bride 2012). Atchison (1996) and Paavilainen (1998) reported that the most important NPFRMs are cereal straw, bamboo 
and bagasse, the rest being reeds, cotton linters, flax and hemp, kenaf, esparto, jute, abaca and sisal. However, the possibility of making pulps from many of these NPFRMs in countries of moderate and boreal climates is limited, because they simply do not grow in these climate conditions.

One of the plants that grows in moderate or boreal climate areas is industrial hemp (Kane 2000; Pahkala et al. 2008). The advantage of hemp over cereal straw is a higher biomass yield per hectare of cultivation (Bawyer 2001; Burczyk et al. 2009; Prade et al. 2011; Consentino et al. 2013; Finnan and Styles 2013; Jankauskiené and Gruzdiené 2015) and lower content of mineral substances than in wheat straw. For papermakers, the yield of dry hemp stalks per hectare is more useful information than the yield of hemp biomass. The ranges of values of this index are quite different, depending on the cultivar of hemp and the geographical area where the cultivation of hemp is located, from a minimum of about $5 \mathrm{t} / \mathrm{ha} / \mathrm{y}$ to as much as $22 \mathrm{t} / \mathrm{ha} / \mathrm{y}$ (Struik et al. 2000; Bawyer 2001; Pahkala et al. 2008; Angelini et al. 2016).

As shown in the literature, the use of industrial hemp has been considered for paper production. Some Canadian researchers have been very active in this area. They studied the chemical composition of a Canadian cultivar of hemp, the kinetics of delignification of hemp stalks, hemp bast and hemp woodycore using the soda method, together with comparison of some morphological properties of pulps (Correia et al. 1998, 2001). In subsequent work, they also compared the results of processing of hemp stalks using soda, soda-anthraquinone (AQ), kraft and kraftAQ methods into pulps (Correia et al. 2003).

Studies of the application of industrial hemp for papermaking purposes has also been conducted in Holland, Hungary, Australia, Spain, China, India, Czech Republic and Poland. They studies were concerned with the processing of hemp raw materials (stalks, woody-core or bast) into soda pulps (Van der Werf et al. 1994; De Groot et al. 1995, 1999; Dutt et al. 2005; Fišerova et al. 2013), organosolv pulps (Zomers et al. 1995; Barberà et al. 2011), thermomechanical pulp (TMP), cold caustic soda (CCS) pulp (Lisson 2001), alkaline peroxide extrusion pulp (APXP; DeJong et al. 1999), enzymatic-mechanical pulp (Ekblad et al. 2005), chemithermomechanical pulp (CTMP), sulphite pulps (Bączyńska et al. 1993; Stupińska and Madaj 1996; Stupińska et al. 2005;
Dutt et al. 2005) and kraft pulps (Danielewicz and Surma-Ślusarska 2010a, 2011; Dutt et al. 2005). Also studied were the kinetics of the delignification of hemp stalks and hemp woody-core (Abdul-Karim et al. 1995; Dang and Nguyen 2006) and properties of bleached pulps from hemp roots (Miao et al. 2014). Kovacs et al. (1992) also pulped hemp stalks using kraft, bisulphite, neutral sulphite and alkaline oxygen methods, but they did not present the properties of the handsheets prepared from these pulps.

The presented review of the literature shows that hemp stalks can be processed into pulps by various methods. However, the properties of cellulosic pulps made from hemp stalks have been examined only in a few of the above-mentioned works. For example, De Groot et al. (1999) and Fišerova et al. (2013) presented the properties of hemp woody-core and hemp stalk soda pulps, respectively, Zomers et al. (1995) studied the density, tensile, tear and burst indices of organosolv hemp stalks, woody-core and bast pulps, DeJong et al. (1999) and Ekblad et al. (2005) presented the same properties of APXP and ezymatic-mechanical pulp, respectively, while Dutt et al. (2005) showed tensile, tear, burst and double fold analysis results of unbleached hemp stalks and hemp bast pulps obtained using different methods.

The results of these works indicate that hemp stalks and unbleached hemp bast pulps obtained using these methods possessed high bulk and tear, while these characteristics in hemp woody-core pulps had low values.

However, the economic effects, e.g. the profitability, of hemp pulp production using some of mentioned methods, especially soda and organosolv, are of great importance. It is necessary to take into account the high investment costs of building a separate mill for the processing of hemp stalks, for example, into unbleached and especially bleached pulps.

A method commonly used in the world's paper industry to produce bleached cellulosic pulps consists of subjecting plant fibrous raw materials (PFRM) to kraft pulping, oxygen delignification and bleaching using elemental chlorine-free (ECF) technology. So, it would be a good idea to compare the properties of hemp stalk, hemp woody-core and hemp bast fibre pulps obtained using the sequence of these processes, especially since there is a lack of data the literature on the properties of bleached kraft pulps processed from these NPFRMs. An enlargement of knowledge in this 
area could help in evaluating the possibilities of joint processing of birch and pine wood with a small addition (a small percentage) of any of these hemp raw materials, which seems to be the best method of introducing hemp into the pulp and paper industry considering the possible use of existing industrial equipment.

This most economically justified solution would fit with the EU's environmental directives, which aim to reduce the consumption of wood fibre in paper and board products, and replace it with other plant biomass, which is produced annually in huge quantities worldwide in a much shorter growing cycle than wood. If the resulting pulp could be characterised by a higher yield from the PFRM and better properties than pulps from wood, then replacing the wood with NPFRM could improve both the final yield and some of the final properties of fibrous semi-manufactured products. Due to the large-scale production of the papermaking industry, this could have both economic and qualitative importance for this industry and the properties of some kinds of papers and boards, respectively.

Based on these assumptions, studies were conducted to evaluate the different properties of bleached hemp stalk, hemp woody-core and hemp bast fibre kraft pulps, which were compared with the properties of bleached kraft pulp from birch and pine. The first two hemp pulps were made from hemp stalks and from hemp woody-core, respectively, according to the sequence: kraft pulping, oxygen delignification and ECF bleaching, while the third pulp was obtained using only oxygen delignification and bleaching (i.e. bypassing the kraft pulping process) due to low lignin content in hemp bast fibres.
The large differences of the properties of these pulps prompted us also to investigate the morphological properties of hemp fibres, their strength and chemical composition, which was necessary in order to explain the observed relationships.

\section{Materials and methods}

\section{Materials}

Hemp stalks (Canabis sativa L.), Białobrzeskie cultivar, cut into 3 to 6-mm segments (marked as $H s$ ), hemp woody-core obtained from hemp stalks not subjected to the retting process $(H w c)$ and hemp bast fibres $(H b f)$ cut into $\sim 3$-mm segments were used in the study. These raw materials are presented in Fig. 1.

Apart from hemp FRMs, birch (Betula pendula; B) and pine (Pinus sylvestris; P) wood chips were also used for production of bleached kraft pulps. Hemp raw materials were kindly granted by the Institute of Natural Fibres in Poznan, while birch and pine were obtained from the International Paper Company in Kwidzyn, Poland.

For characterisation of the chemical composition of samples of hemp FRMs, appropriate analyses were performed according the Polish standard PN-92/P500092. The results of the characterisation are shown in Table 1 in dry basis weight \%. (Danielewicz and Surma-Ślusarska 2010a).

Chemicals of pure grade used for pulping $(\mathrm{NaOH}$, $\left.\mathrm{Na}_{2} \mathrm{~S}\right)$, oxygen delignification $\left(\mathrm{NaOH}, \mathrm{MgSO}_{4}\right)$, as well as preparation of solution of $\mathrm{ClO}_{2}\left(\mathrm{NaClO}_{2}\right.$, $\mathrm{H}_{2} \mathrm{SO}_{4}$ ) were purchased from Sigma-Aldrich. The

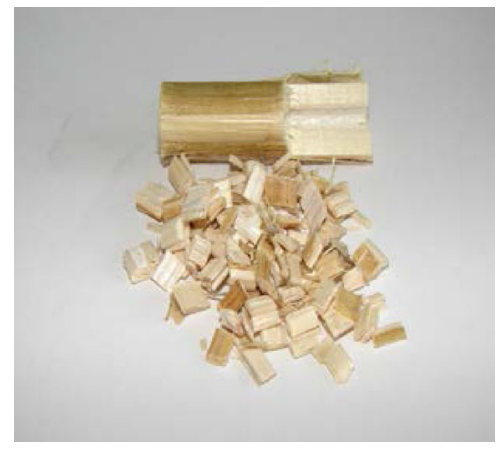

Hemp stalks before and after cutting $(H s)$

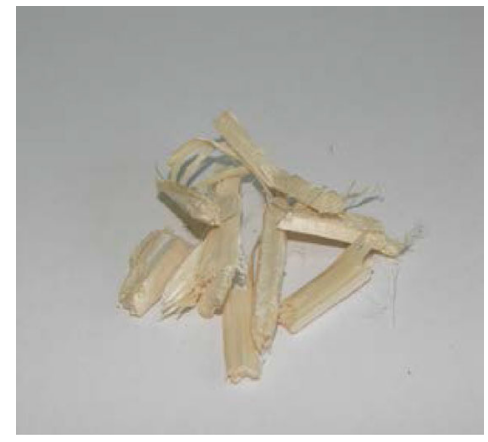

Hemp woody-core $(H w c)$

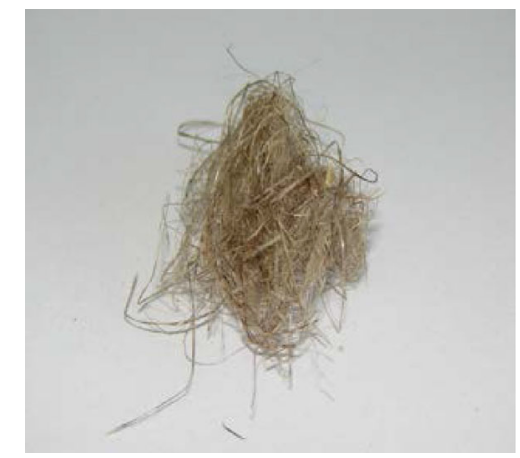

Primary hemp bast fibres $(H b f)$ before cutting

Fig. 1 Hemp fibrous raw materials (FRMs) used in study 
Table 1 Chemical composition of the hemp stalks, hempwoody core and hemp bast fibres

\begin{tabular}{lrcc}
\hline Component (mass\%) & Stalks & Woody-core & Bast fibres \\
\hline Cellulose & 46.9 & 36.3 & 71.7 \\
Lignin & 18.2 & 27.1 & 4.0 \\
Extractives & 1.1 & 1.2 & 0.9 \\
Ash & 1.3 & 1.2 & 1.5 \\
\hline
\end{tabular}

Arithmetic averages of two parallel determinations, the results of which do not differ by more than $0.2 \%$

$\mathrm{ClO}_{2}$ solution was prepared by absorbing the gas released during the reaction of $\mathrm{NaClO}_{2}$ with sulfuric acid in cold water.

\section{Pulping process of PFRM}

Pulping of PFRM was carried out in a Hatoo laboratory digester in 2.5-1 autoclaves. The active alkali charges for hemp stalks, hemp woody-core, birch and pine chips were $15,18,18$ and $22 \%$ for ovendried (o.d.) raw material expressed as $\mathrm{NaOH}$, respectively. For the kraft pulping experiments, the sulphidity of the liquor was $25 \%$, with a liquor-to-wood ratio of $5: 1$ for hemp raw materials and $4: 1$ for birch and pine wood chips. In all the cooking experiments, the temperature was raised to $165{ }^{\circ} \mathrm{C}$ in the first $90 \mathrm{~min}$ and was held there for another $90 \mathrm{~min}$. After cooking, the fibrous material was washed with deionised water, first on dense wire mesh and then by diffusion for $24 \mathrm{~h}$ in a bucket, after which it was disintegrated. The uncooked knots were separated from pulps in a Weverk screen sorter, refined in a Bauer disc refiner until complete fiberisation, added to the unbleached pulp slurry and then mixed with it. After that, pulp slurries were dewatered and stored in a refrigerator for further research. Total yield of unbleached $H_{s}, H_{w c}$, $B$ and $P$ pulps was $57.7,48.4,52.9$ and $46.2 \%$, while the kappa numbers were 24.5, 27.1, 24.2 and 31.7, respectively.

Oxygen delignification of pulps made from hemp stalks, hemp woody-core, birch and pine

A Jayme reactor was used for oxygen delignification of pulps. In all the experiments, the amount of o.d. pulp used was about $100 \mathrm{~g}$. Oxygen delignification experiments were carried out at a consistency of $8 \%$, with an oxygen pressure of $0.6 \mathrm{MPa}$ and at a temperature of $100{ }^{\circ} \mathrm{C}$. At the beginning of each experiment, $0.1 \%$ (on o.d. pulp) of $\mathrm{MgSO}_{4}$ dissolved in $300 \mathrm{ml}$ of water was mixed with the pulp, after which a $\mathrm{NaOH}(0.1 \%$ of $\mathrm{NaOH}$ per kappa number unit of unbleached pulp) was added to the pulp with the rest of the distilled water. The pulp was then mixed with chemicals, placed in the reactor, and oxygen pressure was applied. In all the oxygen delignification experiments, the temperature was raised for $30 \mathrm{~min}$ to $100{ }^{\circ} \mathrm{C}$ and held at this level for another $60 \mathrm{~min}$. After that, the pressure was released, the reactor was opened and the pulps were discharged, filtered and washed with four aliquots of $1000 \mathrm{ml}$ of deionised water. The pulps were then filtered, pressed and stored in a polyethylene bag for further treatment. As a result of oxygen delignification, the kappa number of pulps was reduced by about half. The yields of $H_{s}, H_{w c}, B$ and $P$ pulps in the oxygen delignification process were 96.1, 95.1, 96.5 and $94.2 \%$, while the kappa numbers were $10.1,9.5,11.5$ and 13.9 , respectively.

\section{Oxygen delignification of hemp bast fibres}

Hemp bast fibres were converted into bleached pulp differently from other PFRM. A sample of about $100 \mathrm{~g}$ (o.d.) of these fibres was placed in a polyethylene bag, and then the following chemicals were added sequentially: $0.1 \% \mathrm{MgSO}_{4}$ (in the form of an aqueous solution) and sodium hydroxide in the amount of $1 \%$ to o.d. fibres dissolved in distilled water in an amount ensuring $10 \%$ consistency of fibrous slurry. The contents of the bag were then mixed by squeezing and placed in the Jayme reactor. The autoclave was closed, filled with oxygen and heated to a maximum temperature of $100{ }^{\circ} \mathrm{C}$ for $30 \mathrm{~min}$, at which temperature it remained for another $60 \mathrm{~min}$. After $60 \mathrm{~min}$ of delignification, the pressure was released, the reactor opened and the pulp discharged and washed with four aliquots of $1000 \mathrm{ml}$ of deionised water. It was then filtered, pressed and stored in a polyethylene bag for further treatment. The kappa number of hemp bast fibre pulp after oxygen delignification was lowered from 20.7 to 10.6 units, while the yield of oxygendelignified bast fibres was $90.1 \%$.

Chlorine dioxide bleaching $\left(\mathrm{D}_{0} \mathrm{ED}_{1}\right)$

A total of about $100 \mathrm{~g}$ of o.d. $H s, H w c, H b f, B$ or $P$ pulp was placed in a double-polyethylene bag. After 
that, the chlorine dioxide solution was charged together with an appropriate amount of deionised water to obtain a pulp slurry consistency of $10 \% ; 0.2 \%$ of $\mathrm{ClO}_{2}$ per unit of kappa number was used to bleach hemp pulps (2-3\% of $\mathrm{ClO}_{2}$ per o.d. pulp). Sixty-five per cent of this was added at the $\mathrm{D}_{0}$ stage, and the rest was added at the $D_{1}$ stage. No $\mathrm{pH}$ adjustment of the pulp suspension was made. After one more minute of kneading, the pulp was placed in a water bath with a constant temperature of $75^{\circ} \mathrm{C}$. The bag was kneaded again after another 5 and $30 \mathrm{~min}$. After 60 and $90 \mathrm{~min}$ of bleaching in the $D_{0}$ and $D_{1}$ stages, respectively, the bag was opened. The pulp was then washed via the same method used in the oxygen delignification process and subsequently placed in a plastic bag for further treatment. After the $D_{0}$ stage, the pulp was treated by a hydrogen peroxide-reinforced alkali process $\left(E_{\mathrm{P}}\right.$ stage). The $E_{\mathrm{P}}$ conditions were: deionised water; sodium hydroxide, $1.5 \%$ on o.d. pulp; hydrogen peroxide, $0.6 \%$ on o.d. pulp; pulp consistency, $10 \%$; temperature, $75{ }^{\circ} \mathrm{C}$; time, $90 \mathrm{~min}$; washing, the same as described for the oxygen delignification process. The brightness values of bleached $H s, H w c, H b f, B$ and $P$ pulps were 88.6; 89.6; 90.9 and 93.3 and $90.9 \%$, while the final yields from PFRM were 53.0, 44.9, $85.0,48.2$ and $42.0 \%$, respectively.

\section{Evaluation of pulps' properties}

Beating of pulps was performed in a laboratory Jokro mill according to the PN-EN 25264-3 (1999) standard. A Rapid-Köthen apparatus was used for the preparation of handsheets. For determination of structural, strength and optical properties, handsheets of $75 \pm 3 \mathrm{~g} / \mathrm{m}^{2}$ were prepared according to the PN-EN ISO 5269 (2005) standard using the Rapid-Köthen apparatus. Determination of the zerospan tensile strength (ZSTS) index of hemp pulps was performed using handsheets of $46-86 \mathrm{~g} / \mathrm{m}^{2}$ prepared similarly. Before determination of properties, handsheets were conditioned in accordance with the PN-EN 20187 (2000) standard. The kappa number, viscosity, freeness and water-absorption analyses were performed according to the following standards: PN-85/P50095.02 (1985), ISO 5351-1 (1981), PN-EN ISO 5267-1 (2002) and ISO 12625-8 (2006), respectively. Testing of the pulps' properties requiring special devices was conducted by the methods presented with the name of device and its manufacturer in Table 2.

Characterisation of pulps also involved properties such as the fines content in pulps, determined according to the method described earlier (Danielewicz and Surma-Ślusarska 2010b), the number of fibres in $1 \mathrm{~g}$ of pulps and their dimensions (length and width) and coarseness in the MorFi LB-01 apparatus (TechPap, France). The cell wall thickness of fibres was calculated using an equation presented by SurmaŚlusarska (1989). Lumen width and Runkel ratio were calculated with the use of equations given in Table 2 . Alfa-cellulose in pulps was determined according to TAPPI T 203 test method (1996). The ability of hemp bast fibres for fibrillation was compared with this ability of pine fibres. This was done by comparing the microfibrils index of fibres determined by the MorFi apparatus and their image in a Biolar $\mathrm{T}$ optical microscope (Poland), equipped with a high-resolution camera.

Elaboration of results

The results of the pulps' properties shown in Figs. 2, 3, 4, 5, 6, 7 and 9 are the arithmetic averages of the two determinations performed using two sets of handsheets prepared from samples of pulps of certain beating degree. Determination of the number of fibres

Table 2 Methods and equipment used to evaluate pulps' properties

\begin{tabular}{lll}
\hline Type of test & Method & Device \\
\hline Brightness R457 and opacity & ISO 2470-1 (1999) & SC 01 (Spectrocolor, Poland) \\
Bulk & PN-EN ISO 534 (2012) & Thickness meter 1011 (PTA, Germany) \\
Tensile strength & PN-EN ISO 1924-2 (2010) & Tensile strength tester BZ2.5/TN1S (Zwick/Roell, Germany) \\
Tear strength & PN-EN ISO 1974 (2012) & ProTear tear tester (Thwing-Albert, USA) \\
Fibre length and width & Owner's manual of MorFi LB-01 & MorFi LB-01 (TechPap, France) \\
Zero-span tensile strength & ISO 15361 (2000) & Troubleshooter TS-100 (Pulmac, USA) \\
\hline
\end{tabular}


and the content of fines in pulps, as well as fibre length, width and coarseness measurements were also repeated twice. The results presented in Table 3 are the arithmetic average of two replicates.

The same method of evaluation of the results was used in determining the $\alpha$-cellulose content, water absorption time (WAT) and water absorption capacity (WAC) of pulps, wherein, in determination of WAT and WAC, the number of replicates was three.

\section{Results and discussion}

Figure 2 shows the Schopper-Riegler freeness (SRfreeness) values of bleached hemp pulps and bleached birch and pine pulps after various beating times.

The SR-freeness of bleached kraft pulps made from hemp stalks $(H s)$ and hemp woody-core $(H w c)$ in an unbeaten state amounted to 24 and $29{ }^{\circ} \mathrm{SR}$, respectively. The beating process of these pulps significantly increased the value of this feature. For example, after $10 \mathrm{~min}$ of beating, it increased to $38^{\circ} \mathrm{SR}(H s)$ and $51^{\circ} \mathrm{SR}(H w c)$, respectively whereas in the case of the birch and pine pulps, it increased from 13 to $17{ }^{\circ} \mathrm{SR}$. Thus, the beatability of hemp stalks and hemp woodycore pulp (measured by ${ }^{\circ} \mathrm{SR}$ ) was much better than birch or pine pulps. However, the former pulps are likely to show much worse drainage in the papermaking process than pulps from wood. On the other hand, susceptibility of pulp made from hemp bast fibres

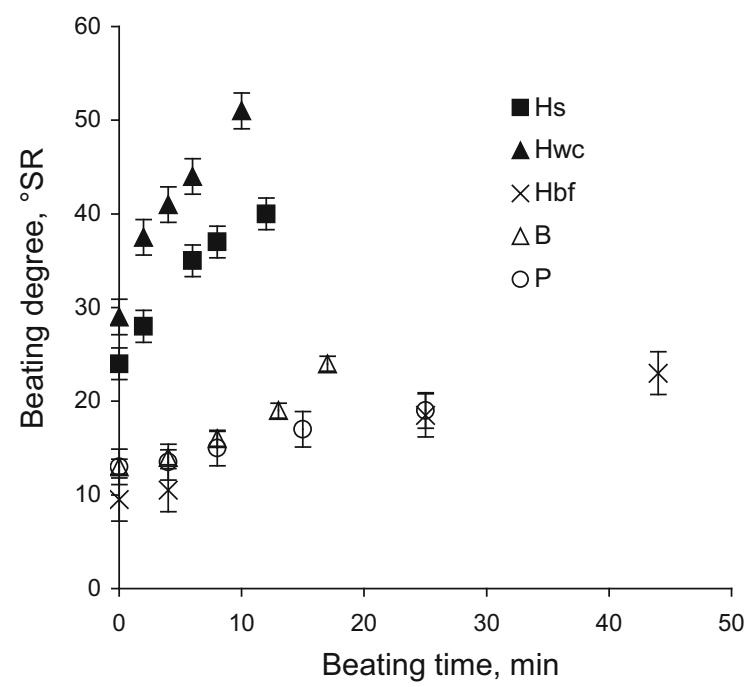

Fig. 2 Beating curves of bleached hemp, birch and pine pulps
$(H b f)$ for the beating was much worse than other hemp pulps studied. After $45 \mathrm{~min}$ of beating, the SRfreeness of this pulp hardly exceeded $23^{\circ} \mathrm{SR}$.

Dry strength of paper is responsible for its good runnability in printing presses. This property of pulps is also important for the possibility of increasing the filler content in paper to achieve the required opacity.

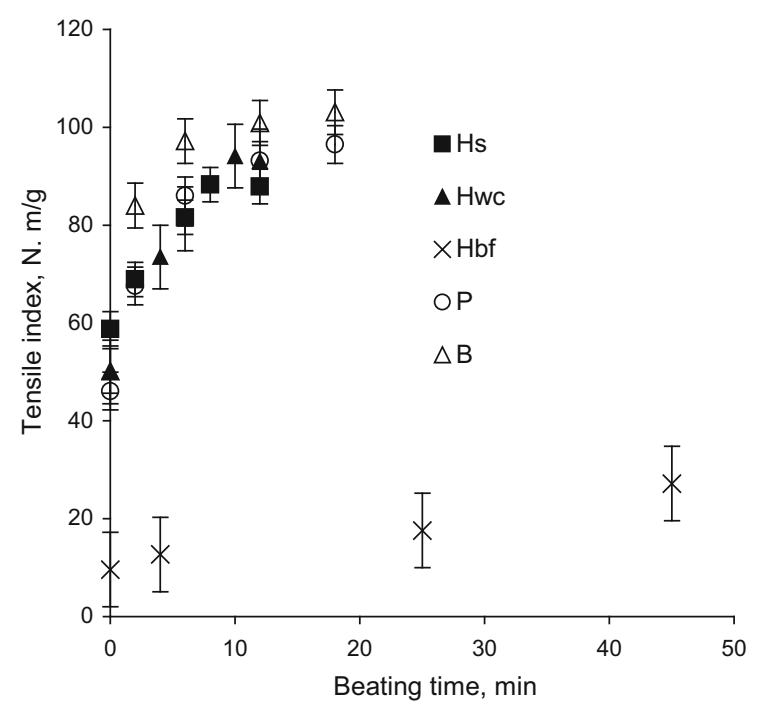

Fig. 3 Tensile strength versus beating time for bleached hemp, birch and pine pulps

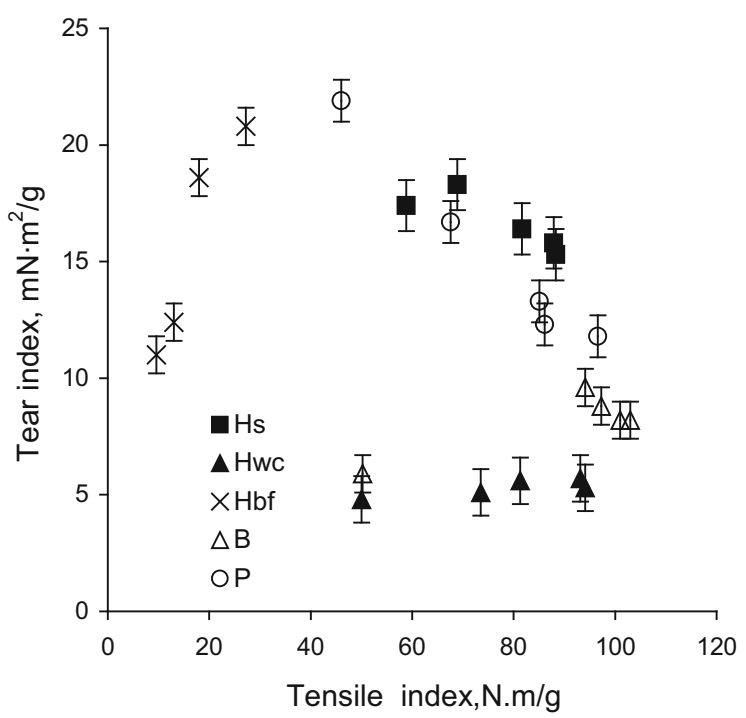

Fig. 4 Tear-tensile strength relationship of bleached hemp, birch and pine pulps 


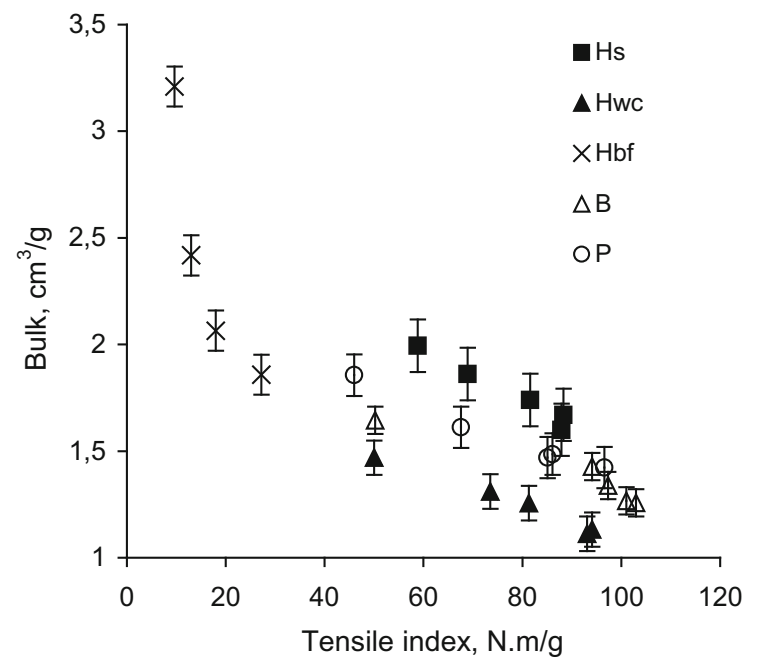

Fig. 5 Bulk-tensile strength relationship of bleached hemp, birch and pine pulps

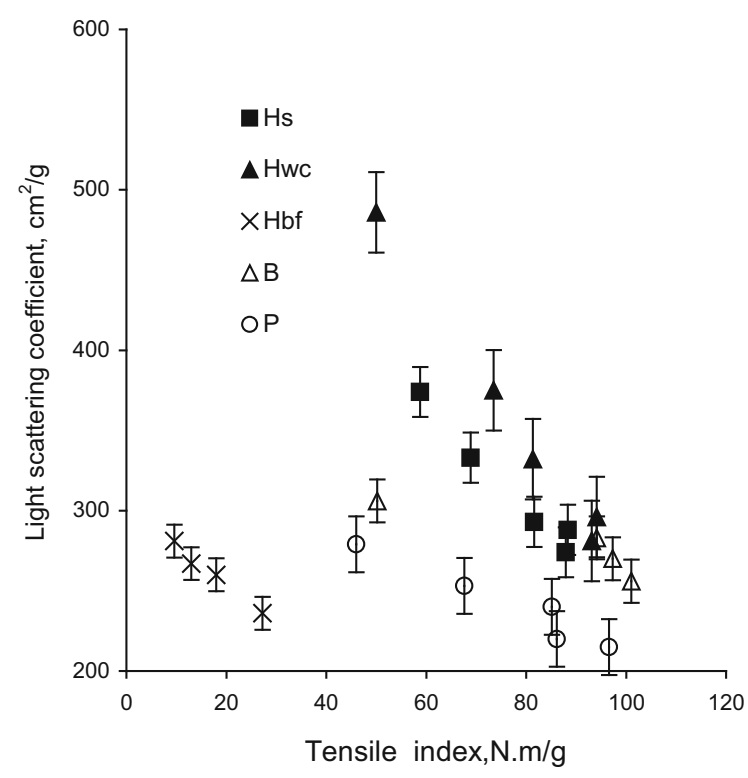

Fig. 6 Light-scattering coefficient-tensile strength relationship of bleached hemp, birch and pine pulps

Figure 3 shows the comparison of the tensile index of handsheets of hemp, birch and pine pulps.

As seen in this Figure, bleached pulp made from hemp stalks has high tensile strength (approximately $60 \mathrm{~N} \cdot \mathrm{m} / \mathrm{g}$ ) even without beating. It is reported that high initial tensile strength of pulps is beneficial because such pulps can be beaten with lower input of energy or used without beating (Wandelt 2007). Kraft

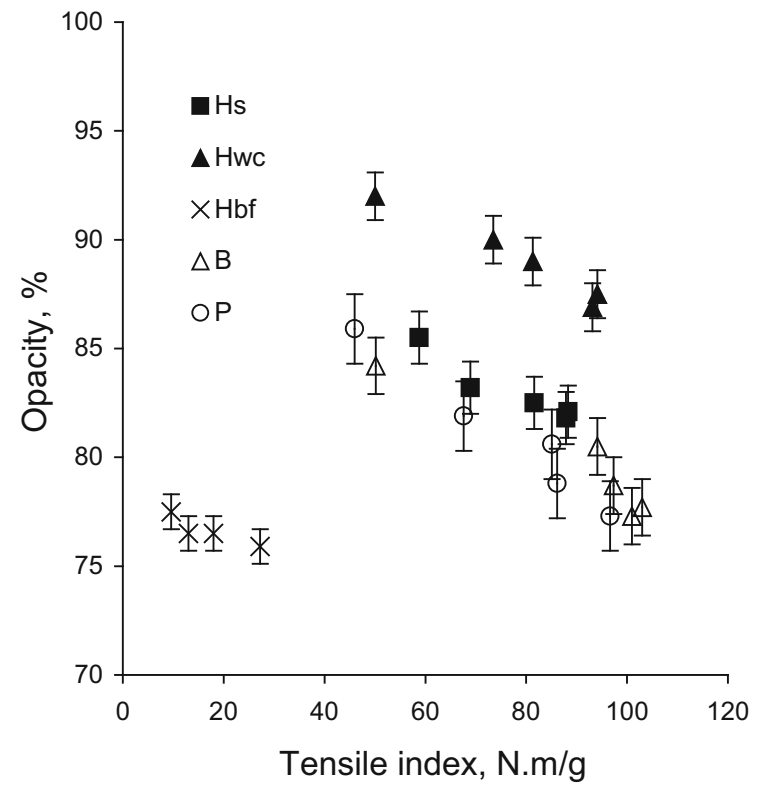

Fig. 7 Printing opacity-tensile strength relationship of bleached hemp, birch and pine pulps

pulps made from hemp stalks and hemp woody-core may reach a high tensile index after beating (approximately $90 \mathrm{~N} \cdot \mathrm{m} / \mathrm{g}$ ). The maximum tensile index of $\mathrm{Hs}$ and $H w c$ pulps was comparable with the maximum tensile index of pine pulp and lower by approximately $10 \mathrm{~N} \cdot \mathrm{m} / \mathrm{g}$, in comparison with birch pulp. The obtained maximal values of tensile index of bleached $H s$ and $H w c$ kraft pulps are somewhat higher than those of unbleached hemp stalk kraft pulp, bleached hemp woody-core soda and organosolv pulps presented by other authors (Zomers et al. 1995; De Groot et al. 1999; Dutt et al. 2005; Fišerova et al. 2013).

The tensile index of hemp bast fibre pulp (Hbf) turned out to be low and much lower than the tensile index of birch and pine pulps even after quite a long beating (45 min) despite reaching similar SR-freeness values compared with pine pulp. The tensile index of hemp bast fibre pulps was also determined by Ekblad et al. (2005) and DeJong et al. (1999). However, they were enzymatic-mechanical and APXP pulps, respectively. The values of this index of these pulps were also on a relatively low level (46-51 N.m/g), but higher than in our study. In the literature, one can also find the data concerning the tensile index of hemp bast organosolv, soda and kraft pulps (Zomers et al. 1995; Dutt et al. 2005). Interestingly, the tensile index of these pulps was higher $(62-66 \mathrm{~N} \cdot \mathrm{m} / \mathrm{g})$ than that of $\mathrm{Hbf}$ 
Table 3 Properties of bleached hemp pulps and birch and pine pulps

\begin{tabular}{lccccc}
\hline Index (unit) & Pulp & & & & \\
\cline { 2 - 6 } & $H s$ & $H w c$ & $H b f$ & $B$ & $P$ \\
\hline Number of fibres per 1 g of pulp $\left(\times 10^{6} / \mathrm{g}\right)$ & 16.98 & 32.25 & 2.64 & 11.07 & 3.84 \\
Fines $(w t \%)$ & 5.7 & 8.3 & 1.0 & 2.7 & 2.2 \\
Length weighted fibre length $(L ; \mathrm{mm})$ & 0.90 & 0.51 & 2.24 & 0.92 & 2.34 \\
Coarseness $(c ; \mathrm{mg} / \mathrm{m})$ & 0.111 & 0.067 & 0.258 & 0.117 & 0.192 \\
Fibre diameter $(D ; \mu \mathrm{m})$ & 22.8 & 23.7 & 20.5 & 21.3 & 30.9 \\
Cell wall thickness $(w ; \mu \mathrm{m})$ & 1.67 & 0.95 & 5.46 & 1.92 & 2.12 \\
Lumen diameter $(d=D-2 w ; \mu \mathrm{m})$ & 19.5 & 21.8 & 9.6 & 17.5 & 26.7 \\
Runkel ratio $(2 w / d)$ & 0.17 & 0.09 & 1.14 & 0.22 & 0.16 \\
\hline
\end{tabular}

than the ones obtained in our work. This can be a result of the method of processing of hemp stalks into pulps, and the hemp cultivars used by these authors. In the world, a lot of cultivars of hemp are known (De Meijer 2002; Grabowska 2004; Jankauskiené and Gruzdiené 2009; Consentino et al. 2013; Angelini et al. 2016). On the other hand, the tear index of handsheets of hemp stalk soda-AQ pulp of freeness up to around $40^{\circ} \mathrm{SR}$ obtained by Fišerova et al. (2013) was similar with the one obtained in our study. On the other hand, the values of tear index of bleached hemp woody-core pulp and hemp bast fibre pulp obtained in our work are in good agreement with that presented by other authors for hemp woody-core pulp (Zomers et al. 1995; De Groot et al. 1999) or hemp bast pulp (De Groot et al. 1999; Dutt et al. 2005).

One of the most important structural properties of pulp is its bulk. Higher bulk enables much stronger calendering of paper, influences positively the stiffness of paper, water absorbency of tissue products, the height of books and the height of tissue rolls. The bulk of hemp pulps was compared with the bulk of birch and pine pulps in Fig. 5.

Figure 5 shows that the pulp produced from hemp stalks $(H s)$ at the level of $60-90 \mathrm{~N} \cdot \mathrm{m} / \mathrm{g}$ of the tensile index had relatively high values of this ratio $\left(1.60-1.95 \mathrm{~cm}^{3} / \mathrm{g}\right)$. In contrast, the bulk of the hemp woody-core pulp was low $\left(1.25-1.35 \mathrm{~cm}^{3} / \mathrm{g}\right)$. As for the bulk of the hemp bast fibre pulp (Hbf) it was high in both the unbeaten and beaten state. In the first case, it amounted to approximately $3.2 \mathrm{~cm}^{3} / \mathrm{g}$, while in the second case (after $45 \mathrm{~min}$ of beating in the Jokro mill), it was $1.9 \mathrm{~cm}^{3} / \mathrm{g}$. One of the reasons for the high bulk of $H b f$ pulp is certainly the low degree of bonding of its fibers (tensile index of $10-27 \mathrm{~N} \cdot \mathrm{m} / \mathrm{g}$ ). It seems that 
high bulk of $H b f$ pulp can be used in practice similarly as the high tear index of this pulp.

Out of optical properties, light-scattering ability and opacity were determined. The light-scattering ability and opacity of $H s, H w c, H b f$, birch and pine pulps are presented in Figs. 6 and 7, respectively.

The highest values of light-scattering coefficient and opacity were obtained in the case of handsheets prepared from hemp woody-core pulp, and the lowest values were obtained from the hemp bast fibre pulp. The hemp stalk pulp at $80-90 \mathrm{~N} \cdot \mathrm{m} / \mathrm{g}$ had similar or slightly better optical characteristics in comparison with birch pulp.

An important feature of bleached pulps, especially for hygienic tissue products, is their water-absorption time (WAT) and water-absorption capacity (WAC). A comparison of these properties of unbeaten bleached pulps is shown in Fig. 8.

Figure 8 shows that the average value of the WAT (left axis in Fig. 8) was lowest for bleached pine pulp and highest for hemp woody-core pulp. This time is similar for $H s, H b f$ and birch pulps. WAC (right axis in Fig. 8) was higher for bleached birch and pine pulps than for hemp pulps by approximately 20\%. The results suggest that the indices studied are more

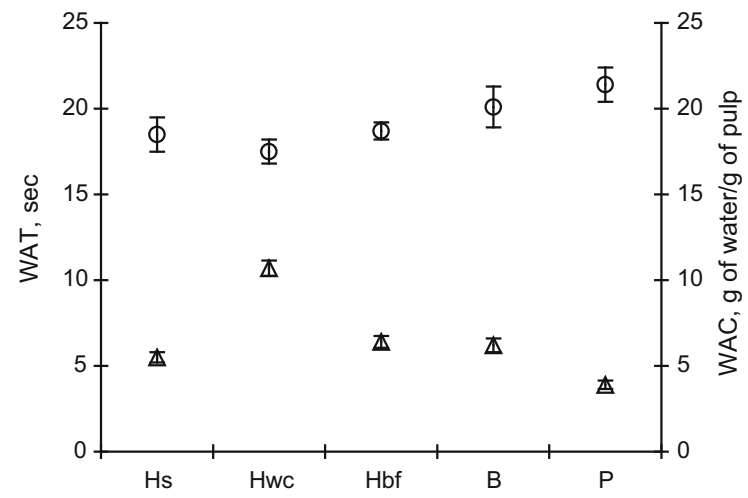

Fig. 8 Water-absorption time (WAT) and water-absorption capacity (WAC) of unbeaten bleached hemp, birch and pine pulps favourable for pulps that are characterised by longer fibres and/or more uniform distribution of fibre length. The lower WAC of Hs and Hwc pulp than birch pulp can be explained by a lower bulk of the former pulps in fluffed state than birch pulp, which results from higher fines content in hemp pulps and the presence of a fraction of short fibres in them. On the other hand, a lower WAC of $H b f$ pulp as compared to birch pulp when fluffed may result from too large of pores in the case of the former pulp, which were unable to hold water that leaked out more readily from this pulp.

In order to clarify the differences between the properties of hemp pulp and pulp from wood, further analyses, calculations and experiments were performed. The results of these analyses are presented in Tables 3, 4 and Figs. 9-11.

The data of Table 3 show that the hemp woodycore pulp contained approximately $32 \times 10^{6}$ fibres per gram of pulp. This is around threefold higher than birch pulp. The number of fibres in hemp bast fibre

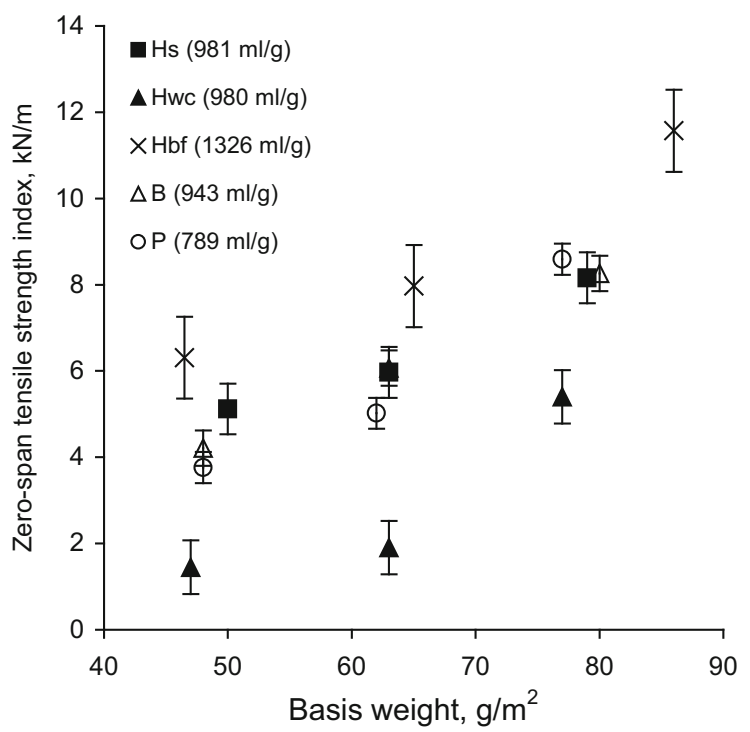

Fig. 9 The zero-span tensile strength index of handsheets prepared from bleached hemp, birch and pine pulps and the intrinsic viscosity of these pulps (in the legend of the figure)

Table 4 Content of $\alpha$-cellulose in pulps

\begin{tabular}{llllll}
\hline Index (unit) & Pulp & & & \\
\cline { 2 - 5 } & $H s$ & $H w c$ & $H b f$ & $B$ & $P$ \\
\hline$\alpha$-Cellulose content (\%) & $87.3 \pm 0.3$ & $81.7 \pm 0.2$ & $97.4 \pm 0.2$ & $82.5 \pm 0.3$ & $89.7 \pm 0.3$ \\
\hline
\end{tabular}


pulp was only about $2.6 \times 10^{6}$ fibres per gram of pulp, i.e., less by about one million than in pine pulp. The number of fibres in $\mathrm{Hs}$ pulp has an intermediate value of about $17 \times 10^{6} / \mathrm{g}$. A similar trend can be observed in the case of fines content. Hemp woody-core pulp has a fines content about threefold higher than birch pulp, while for the hemp bast fibre pulp, it was lowest among the pulps studied.

The differences in fibre content between pulps can be explained by differences in fibre length and coarseness. Hemp woody-core fibres $(H w c)$ have low length and low coarseness, and these are the main reasons for high numbers of fibres in $1 \mathrm{~g}$ of this pulp. On the other hand, hemp bast fibre pulp has high average coarseness and average fibre length similar to pine pulp. Thus, the number of fibres in $1 \mathrm{~g}$ of this pulp is lower than in the case of pine pulp.

Differences in the number of fibres in $1 \mathrm{~g}$ of pulp explain significant differences in optical properties of pulps, while the number of fibres in $1 \mathrm{~g}$ of pulp and fines content explains the SR-freeness variation amongst pulps.

The calculated Runkel ratio indicates that $H b f$ pulp has approximately several times higher fibre stiffness in the unbeaten state than the fibres of birch and pine pulps. This is largely due to high cell wall thickness of hemp bast fibres, but the high degree of crystallinity of hemp bast fibres cellulose, reported by Thygesen et al. (2005), can also have some influence on hemp fibre stiffness. Cell wall thickness of fibres from hemp bast was also determined by Dutt et al. (2005). They reported a mean value of this index of $6.7 \mu \mathrm{m}$, i.e., $23 \%$ more than in our research. On the other hand, $H w c$ fibres are characterised by a Runkel ratio about twelve times lower than that of hemp bast fibres. This results from low cell wall thickness of hemp woodycore fibres $(0.95 \mu \mathrm{m})$.

The Runkel ratios and cell wall thicknesses partly explain the good tensile strength of $H s$ and $H w c$ pulps, the low tensile index of $H b f$ pulp and the differences in bulk between pulps from hemp. As for the cell wall thickness of fibres of pulp from hemp woody-core, Dutt et al. (2005) reported quite different value of the feature $(7.05 \mu \mathrm{m})$. This indicates the possibility of significant differences in cell wall thickness of hemp woody-core amongst different hemp cultivars. The higher values of cell wall thickness of fibres in hemp bast and hemp woody-core obtained by Dutt et al. (2005) seem to explain the lower tensile index of handsheets prepared from hemp stalk kraft pulp obtained by these authors than that obtained in our work.

Stiffness of fibres is not the only factor that influences the properties of pulp handsheets. For example, tensile strength depends also on the ZSTS and shear bond strength per unit of bonded area. The first property depends mainly on intrinsic viscosity, but the second one is primarily influenced by the hemicellulose content of fibres and the degree of the fibres' external fibrillation (Page 1969; I'Anson et al. 2006). The strength of fibres of studied pulps was compared using the ZSTS results, which are presented in Fig. 9.

The data of Fig. 9 indicate that fibres of $H b f$ pulp are strongest among the studied pulps. This partly results from the higher intrinsic viscosity of $H b f$ pulp than other ones. Thus, the fiber strength of $H b f$ pulp is not the reason for the lower tensile strength of this pulp.

The hemicellulose content in pulp may also have a significant effect on its tensile index, and this was determined indirectly through determination of the $\alpha$ cellulose content. These results show that the hemicellulose content in $H b f$ pulp is lowest among the pulps (probably around 2\%), because of the highest $\alpha$ cellulose content in this pulp (Table 4).

High $\alpha$-cellulose content in $H b f$ pulp together with the high yield of this pulp (85\%) are very promising results from the point of view of using it as a pulp destined for chemical processing, because the yield of such pulps obtained from wood with the use of a kraft method is usually low (about 35\%; Surewicz and Rutkowski 1958).

As mentioned, the second factor that influences the shear bond strength of fibres in a sheet is the degree of their external fibrillation. In order to compare the ability for fibrillation of $\mathrm{Hbf}$ pulp fibre and pulps from wood, experiments consisting of beating pulp samples in the Jokro mill for $60 \mathrm{~min}$ and subsequent observation of fibres in the optical microscope were performed. The photographs of fibres after being beated are presented in Figs. 10 and 11.

From Figs. 10 and 11, it can be seen that fibres of Hbf pulp, after the same beating, are more fibrillated than fibres of pine pulp. This conclusion was also confirmed by the results of computer image analysis in the MorFi apparatus. The participation rate of the fibrils in the total length of bast fibres after $60 \mathrm{~min}$ of beating in the Jokro mill was $2.5 \%$, while for the pine 

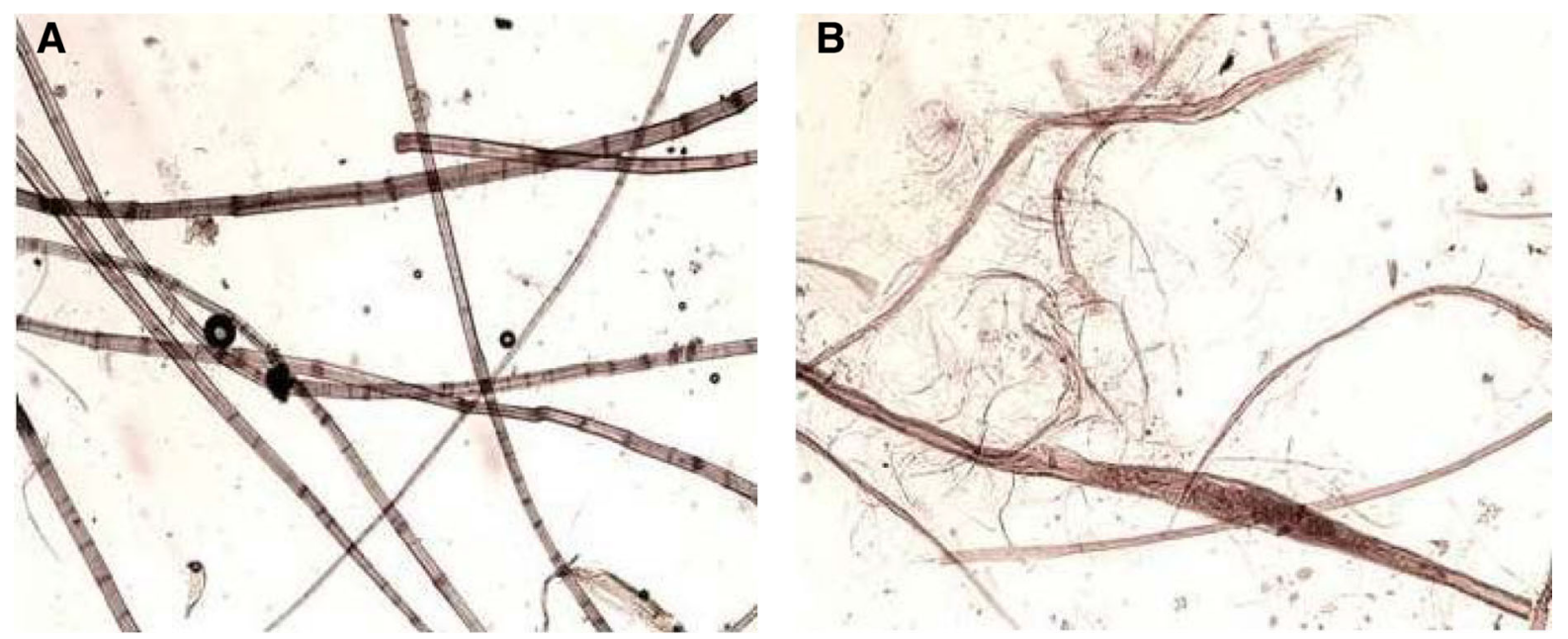

Fig. 10 Unbeaten (a) and beaten (b) hemp bast fibres (optical microscope area, magn. $\times 100$ ) after being beaten in the Jokro mill for $60 \mathrm{~min}$
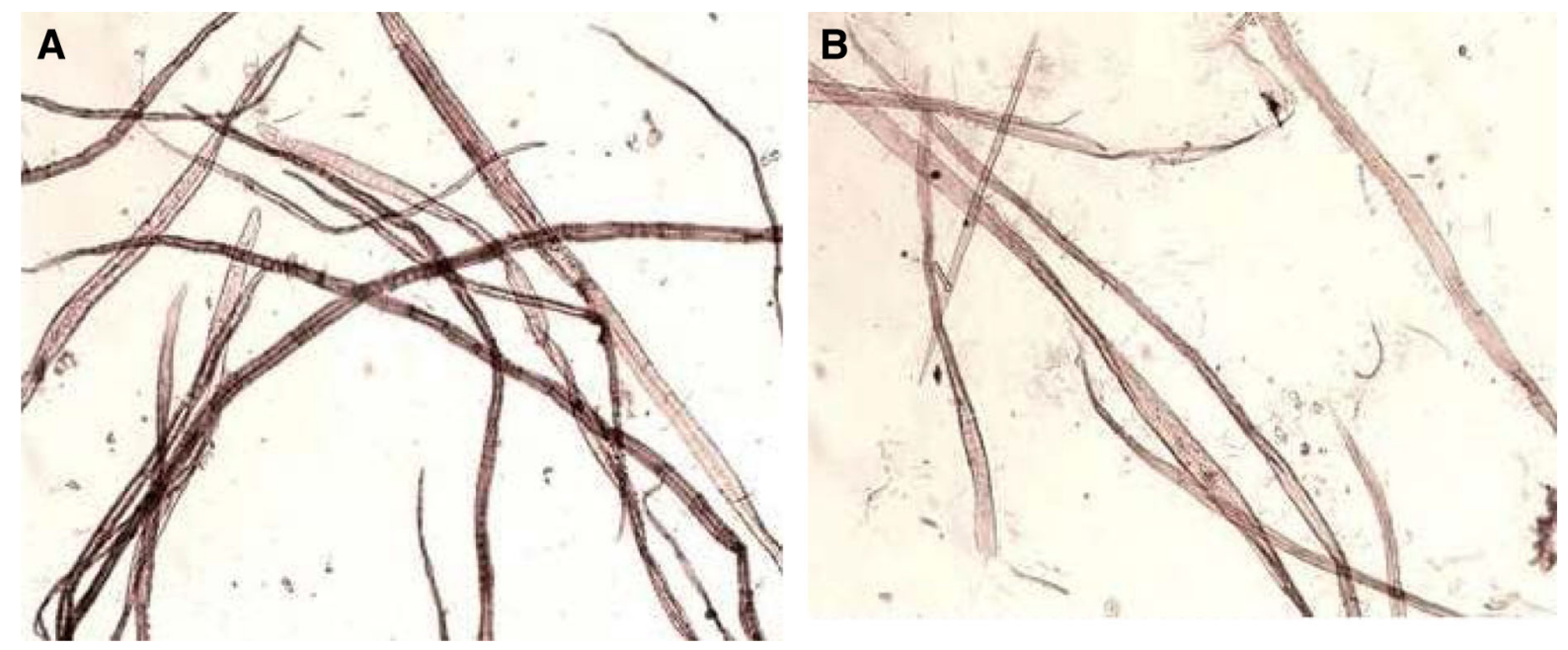

Fig. 11 Unbeaten (a) and beaten (b) pine fibres (optical microscope area, magn. $\times 100$ ) after being beaten in the Jokro mill for 60 min

pulp, it was only $1.0 \%$. Thus, the susceptibility of fibres of $H b f$ for fibrillation can't be the reason for the low tensile index of handsheets of this pulp.

\section{Conclusions}

1. Of the bleached kraft pulps produced from industrial hemp, hemp stalk pulp had the best papermaking properties. This pulp is characterised by a tensile index similar to birch pulp, a higher tear resistance and bulk than pine pulp, and a light scattering ability and opacity that is comparable with birch pulp after beating. This, together with a higher final yield of bleached hemp stalk pulp than birch and pine pulps, indicates that replacing some of the wood with hemp stalks can bring some economic and qualitative benefits to the pulp mill, if the price of the material is comparable to the price of wood.

2. Handsheets of paper prepared from bleached kraft hemp woody-core pulp have a tensile strength comparable with that of bleached kraft birch and pine pulps, and better optical properties than these pulps, but significantly lower bulk and tear. 
Another drawback of this pulp is the evident "semolina-like" consistency of its slurry. This property is rather adverse in papermaking, but it is not excluded that it may be a positive feature for some kinds of specialty papers or composites of plant fibres with thermoplastics.

3. The results of the study confirmed that the bleached hemp bast fibre pulp can be produced using only oxygen-alkaline delignification and the bleaching process (i.e. without the kraft pulping process). It is characterised by high tear resistance and high bulk, but a low breaking length and low ability to scatter light. The high bulk and tear strength, as well as high $\alpha$-cellulose and low hemicellulose content of this pulp, make it a potential fibrous material for the production of high-bulk specialty papers, improvement of the bulk and tear index of pulps characterised by low values of these properties (e.g. wheat straw pulp, waste paper pulps) and chemical processing, respectively.

4. The properties of the bleached pulps made from different hemp raw materials can be explained by the morphological, physical and chemical properties of their fibres. For example, it was shown that the main reason for the varying strength properties of bleached hemp bast fibres in the beating process is the specific structure of their cell wall, as evidenced by the several-timeshigher cell wall thickness and Runkel index, their low hemicellulose content and their relatively low content per unit weight of pulp.

Open Access This article is distributed under the terms of the Creative Commons Attribution 4.0 International License (http:// creativecommons.org/licenses/by/4.0/), which permits unrestricted use, distribution, and reproduction in any medium, provided you give appropriate credit to the original author(s) and the source, provide a link to the Creative Commons license, and indicate if changes were made.

\section{References}

Abdul-Karim LA, Rab A, Polyànszky É, Rusznàk I (1995) Kinetics of delignification in kraft pulping of wheat straw and hemp. TAPPI J 78:161-164

Angelini LG, Tavarini S, Di Candilo M (2016) Performance of new and traditional fiber hemp (Cannabis sativa) cultivars for novel applications: stem, bark, and core yield and chemical composition. J Nat Fibers 13(2):238-252. doi:10. 1080/15440478.2015.1029193

Atchison JE (1996) Twenty-five years of global progress in nonwood plant fibre repulping. Tappi J 79:87-95

Bach B, Fiehn G (1972) New possibilities for carbohydrate stabilization in alkaline pulping of wood. Zellst Pap 2:3-7

Bączyńska K, Madaj R, Stupińska H (1993) Production of pulp from long-fibre annual plants by eco-friendly method. In: International conference PROGRESS'93, 27-30 Aug 1993, Lodz, Poland (in Polish)

Barberà L, Pèlach MA, Pérez I, Puig J, Mutjé P (2011) Upgrading of hemp core for papermaking purposes by means of the organosolv process. Ind Crop Prod 34:865-872. doi:10.1016/j.indcrop.2011.02.005

Bawyer JL (2001) Industrial hemp (Cannabis sativa L.) as papermaking raw material in Minnesota: technical, economical and environmental considerations. Forest Products Management Development Institute. https://www. votehemp.com/PDF/hemp.pdf

Bride J (2012) Australia and New Zealand Pulp and Paper Industry Guide, APPITA

Burczyk H, Grabowska L, Strybe M, Konczewicz W (2009) Effect of sowing density and date of harvest on yields of industrial hemp. J Nat Fibers 6:204-218. doi:10.1080/ 15440470902972588

Christersson L (2010) Wood production potential in poplar plantations in Sweden. Biomass Bioenergy 34:1289-1299. doi:10.1016/j.biombioe.2010.03.021

Consentino SL, Riggi E, Testa G, Scordia D, Copani V (2013) Evaluation of European developed fibre hemp genotypes (Cannabis sativa L.) in semi-arid Mediterranean environment. Ind Crop Prod 50:312-324. doi:10.1016/j.indcrop. 2013.07.059

Correia F, Roy DN, Goel K (1998) Pulping of Canadian industrial hemp (Cannabis sativa L.). Pulp Pap Can 99:39-41

Correia F, Roy DN, Goel K (2001) Chemistry and delignification kinetics of Canadian industrial hemp (Cannabis sativa L.). J Wood Chem Technol 21:97-111

Correia F, Roy DN, Chute W (2003) Hemp chemical pulp: a reinforcing fibre for hardwood kraft pulps. Pulp Pap Can 104:51-53

Dang V, Nguyen KL (2006) Characterisation of the heterogeneous alkaline pulping kinetics of hemp woody-core. Bioresour Technol 97:1353-1359. doi:10.1016/j.biortech. 2005.07.008

Danielewicz D, Surma-Ślusarska B (2010a) Processing of industrial hemp into papermaking pulps intended for bleaching. Fibres Text East Eur 18:110-115

Danielewicz D, Surma-Ślusarska B (2010b) Application of computer image analysis for characterization of various papermaking pulps. Cell Chem Technol 44:285-291

Danielewicz D, Surma-Ślusarska B (2011) Characterization of bleached hemp pulps with the use of computer image analysis method. Fibres Text East Eur 19:96-1012

Danielewicz D, Surma-Ślusarska B, Żurek G, Martyniak D, Kmiotek M, Dybka K (2015) Selected grass plants as biomass fuels and raw materials for papermaking, part II. Pulp and paper properties. Bioresources 10:8552-8564. doi:10.15376/biores.10.4.8552-8564 
De Groot B, Van Dam JEG, Van't Riet K (1995) Alkaline pulping of hemp woody core: kinetic modelling of lignin, xylan and cellulose extraction and degradation. Holzforschung 49:332-342

De Groot B, Van der Kolk JC, Van Dam JEG, Van T'Riet K (1999) Papermaking characteristics of alkaline hempwoody-core pulps. TAPPI J 82:107-112

De Meijer E (2002) Fibre hemp cultivars: a survey of origin, ancestry, availability and brief agronomic characteristics. http://www.hempfood.com/IHA/iha02207.html

DeJong E, van Roekel GJ, Snijder MHB, Zhang Y (1999) Toward s industrial application of bast fibre pulps. Pulp Pap Can 100:T220-T273

Dutt D, Upadhyaya JS, Malik RS, Tyagi CH (2005) Studies on the pulp and papermaking characteristics of some Indian non-woody fibrous raw materials. Cell Chem Technol 39: $115-128$

Edelman R (2000) Non-wood pulp mill concept-environment and economics. Pap Puu Pap Tim 82:68-172

Ekblad C, Pettersson B, Zhang J, Jernberg S, Henriksson G (2005) Enzymatic-mechanical pulping of bast fibres from flax and hemp. Cell Chem Technol 39:95-103

Finnan J, Styles D (2013) Hemp: a more sustainable annual energy crop for climate and energy policy. Energy Policy 58:152-162. doi:10.1016/j.enpol.2013.02.046

Fišerova M, Gigac J, Illa A (2013) Soda-AQ pulping of hemp stalks and pulp properties. Pap Celul 68:10-13

Ford MJ, Sharman PM (1996) HYH spells a good deal for the future. Pulp Pap Int 38(10):29, 31, 32, 37, 39

Grabowska L (2004) Polish varieties of fibrous hemp present in COBOR register. Flax Hemp 1:15-23 (in Polish)

Guadalix ME, Almendros GA, Martínez T, Camarero S, Barrasa JM, Pelayo M (1996) Comparative analysis of wheat straw paperboards prepared after biomechanical and semichemical pulping. Bioresour Technol 57:217-227. doi:10. 1016/S0960-8524(96)00014-4

Hart PW, Rudie AW (2014) Anthraquinone: a review of the rise and fall of a pulping catalyst. TAPPI J 13:23-31

I'Anson SJ, Karademir A, Sampson WW (2006) Specific contact area and the tensile strength of paper. APPITA J 59:297-302

ISO 5351-11(1981) Cellulose in dilute solutions - Determination of limiting viscosity number-part 1 : method in cupriethylene-diamine (CED) solution

ISO 12625-8 Standard (2006) Tissue paper and tissue products-part 8: water-absorption time and water absorption capacity, basket-immersion test method. International Organization for Standardization, Geneva

ISO 15361 Standard (2000) Pulps. Determination of zero-span tensile strength, wet or dry. International Organization for Standardization, Geneva

ISO 2470 Standard (1999) Paper, board and pulps-determination of diffuse blue reflectance factor (ISO brightness). International Organization for Standardization, Geneva

Jain RK, Singh K, Kulkarni AG (2005) The Indian paper industry: towards sustainability. Pulp Pap Int 44(3):33-37

Jankauskiené Z, Gruzdiené E (2009) Beniko and Białobrzeskie -industrial: hemp varieties in Lithuania. In: Proceedings of the 7th international scientific and practical conference, Rezekne, 25-27 June, vol 1, Rezekne, pp 176-182
Jankauskiené Z, Gruzdiené E (2015) Screening of industrial hemp (Cannabis sativa L.) cultivars for biomass yielding capacities in Lithuania. J Nat Fibers 12(4):368-377. doi:10.1080/15440478.2014.929556

Kane M (2000) Getting a problem fibre? Hemp is at hand. Pulp Pap Int 42:33-35

Kovacs I, Rab A, Rusznal I, Annus S (1992) Hemp (Cannabis sativa) as a possible raw material for the paper industry. Cell Chem Technol 26:627-635

Lisson SN (2001) Studies of fibre hemp and flex pulps as a feedstock for Australian newsprint production. APPITA J 54:449-456

Meeusen-van OMJG (1996) Getting back to basics with European agro-fibres. Pulp Pap Int 38(5):65

Miao C, Hui LF, Liu Z, Tang X (2014) Evaluation of hemp root bast as a new material for papermaking. BioResources 9:132-142

Miranda R, Bobu E, Grossman H, Stawicki B, Blanco A (2010) Factors influencing a higher use of recovered paper in the European paper industry. Cell Chem Technol 44:419-430

Paavilainen L (1998) European prospects for using non-wood fibres. Pulp Pap Int 40(6):61-66

Page DH (1969) A theory for the tensile strength of paper. TAPPI J 52:674-681

Pahkala K, Pahkala E, Syrjälä H (2008) Northern limits to fibre production in Europe. J Ind Hemp 13:104-116. doi:10. 1080/15377880802391084

PN-85/P50095.02 (1985) Fibrous papermaking semi-finished products-determination of degree of pulping of fibrous cellulose pulp-determination of Kappa number. Polish Committee for Standardization, Warsaw

PN-EN ISO 1924-2 (2010) Paper and paperboard. Determination of properties of paper and paperboard exposed to tensile forces-part 2: the test at a constant stretching speed $(20 \mathrm{~mm} / \mathrm{min})$. Polish Committee for Standardization, Warsaw, Poland

PN-EN 20187 (2000) Paper, board and fibrous pulps-normalized conditions of conditioning and testing of samples. Polish Committee for Standardization, Warsaw

PN-EN 25264-3 (1999) Fibrous pulps-laboratory beating-the Jokro mill method. Polish Committee for Standardization, Warsaw

PN-EN ISO 1974 (2012) Paper-determination of tearing resistance -Elmendorf method. Polish Committee for Standardization, Warsaw

PN-EN ISO 5267-1 (2002) Pulps-determination of the degree of beating-part 1: Schopper-Riegler method. Polish Committee for Standardization, Warsaw

PN-EN ISO 534 (2012) Paper and paperboard-determination of thickness, density and bulk. Polish Committee for Standardization, Warsaw

PN-EN-ISO 5269-1 (2005) Pulps-preparation of laboratory paper handsheets for testing physical properties-part 1 : the conventional method of forming of handsheets. Polish Committee for Standardization, Warsaw

Potter C (1996) Century turns with bagasse as the favorite. Pulp Pap Int 38(4):33-37

Prade T, Svensson SE, Andersson A, Mattsson JE (2011) Biomass and energy yield of industrial hemp grown for biogas and solid fuel. Biomass Bioenergy 35:3040-3049. doi:10. 1016/j.biombioe.2011.04.006 
Sadawarte NS (1995) Better technology needed to clean up nonwood fiber. Pulp Pap Int 37(6):84-95

Schott S, Chaussy D, Mauret E (2001) Utilization of straw for the production of pulp and paper. Pap Puu Pap Tim 83:453-457

Struik PC, Amaducci S, Bullard MJ, Stutterheim NC, Venturi G, Cromack HTH (2000) Agronomy of fibre hemp (Cannabis sativa L.) in Europe. Ind Crop Prod 11:107-118. doi:10. 1016/S0926-6690(99)00048-5

Stupińska H, Madaj R (1996) Production of pulps from nonwood fibrous raw materials: Annual plants. In: Proceedings of international conference PROGRESS'96, 17.19.1996, Lodz, Poland (in Polish)

Stupińska H, Palenik J, Kopania E, Malinowski T, Wójcik M, Grządzielewski P, Czepczyński A (2005) Bleached pulp from hemp straw. In: Proceedings of international conference PROGRESS'06, 05.08.2005, Lodz, Poland (in Polish)

Surewicz W, Rutkowski J (1958) Development directions of production of textiles pulps. Przegl Papiern 14:83-91 (in Polish)

Surma-Ślusarska B (1989) Direct and indirect indices of evaluation of dimensions of wood fibres and cellulosic pulps. Przegl Papiern 45:389-393 (in Polish)

TAPPI Test methods T203 (1996) Alpha-, beta-, and gammacellulose in pulp. TAPPI Press, New York
Tarnawski W (2006) The future in plantations of wood. Przegl Papiern 62:32-34 (in Polish)

Thygesen A, Oddershede J, Lilholt H, Thomson AB, Kenny S (2005) On the determination of crystallinity and cellulose content in plant fibres. Cellulose 12:563-576. doi:10.1007/ s10570-005-9001-8

Van der Werf HMG, Harsveld van der Veen JE, Bouma ATM, Ten Cate M (1994) Quality of hemp (Cannabis sativa L.) stems as a raw material for paper. Ind Crops Prod 2:219-227

Vargas F, Gonzàlez Z, Sànchez R, Jiménez L, Rodriguez A (2012) Cellulosic pulps of cereal straws as a raw material for the manufacture of ecological packaging. BioResources 7:4161-4170

Wandelt P (2007) Modern methods of selection of the reinforcement pulp. Przegl Papiern 63:93-94 (in Polish)

Xiaorong N, Oinonen H (2007) Non-wood still the main virgin fibre. Pap Puu-Pap Tim 89:284-286

Zhu A (2008) Straw: the eco friendly choice. Pulp Pap Int 49(4):25-27

Zomers FHA, Gosselink RJA, Van Dam JEG, Tjeerdsma BF (1995) Organosolv pulping and test paper characterization of fiber hemp. TAPPI J 78:149-155 